\title{
Advising a woman with suspected Zika virus infection
}

\author{
RICHARD CASH, MARCIA C CASTRO
}

The Zika virus (ZIKV) epidemic is spreading: 67 countries are now reporting transmission, and over 2,000 cases of congenital Zika syndrome (CZS) have been confirmed.

The heaviest burden has been borne by those living where poverty, poor infrastructure, and lack of access to health services are common and the penetration of Aedes aegypti is high. Because most cases are asymptomatic, the most dramatic signs of the disease appear through the CZS cases. In spite of the need for disaggregated epidemiological data to understand transmission patterns and evaluate interventions in vulnerable populations, there is no reliable count of ZIKV cases by sex and ethnicity (1).

WHO's interim guidance on pregnancy management in the context of a ZIKV infection includes recommendations for preventing and managing infection in pregnant women. Vector control is emphasised, as well as personal protection such as clothing, bed nets, repellents, and safe sex (2). These recommendations, duly relayed by health authorities, don't always resonate in the poorest neighbourhoods of Brazil, El Salvador, and other affected countries, where the availability, practicality, and affordability of protective items are doubtful, and where safe sex is not always negotiable. When prevention fails, pregnant women and other women of reproductive age are faced with difficult decisions against a background of uncertainties.

Basic reproductive services may be lacking or inaccessible. In many cases, restrictive abortion laws curtail their ability to thwart the consequences of the virus for their health and that of their children.

El Salvador, a Central American country with a population of 7 million, most of whom are Roman Catholic or Evangelical Christians, has been hit by ZIKV. There have been an estimated 5,400 cases of ZIKV, 100 of which were in pregnant women. El Salvador has urged all women to delay pregnancy until 2018. In Central America it is estimated that $74 \%$ have access to contraceptives. With physicians across Central and Latin America urging women to postpone pregnancy because of

Authors; Richard A Cash (racash@hsph.harvard.edu), Marcia C Castro (mcastro@hsph.harvard.edu), Department of Global Health and Population, Harvard T H Chan School of Public Health, 665 Huntington Avenue, Boston, MA, 02115, USA.

To cite: Cash RA, Castro MC. Advising a woman with suspected Zika virus infection. Indian J Med Ethics. 2018 Apr-Jun;3(2) NS:163-4. DOI:10.20529/ IJME.2018.033

CIndian Journal of Medical Ethics 2018
ZIKV, Pope Francis said that using contraceptives could be a "lesser evil" when a baby would have a high risk of birth defects; but he added, "Abortion is not a lesser evil -- it's a crime. It is the deliberate taking of an innocent human life... It's an absolute evil...Don't confuse avoiding pregnancy with abortion."(3)

The government of El Salvador has some of the strictest anti-abortion laws. Abortion is banned without exception, including after rape, incest, severely deformed foetus diagnosis, and when a woman's life is in danger. Under Salvadoran law, doctors must report women whom they suspect of having induced an abortion. It is strictly illegal for doctors to provide abortion services, and to advise on how to procure them.

The Citizen Group for the Decriminalization of Therapeutic, Ethical, and Eugenic Abortion (CFDA), a local rights group, says the abortion ban causes maternal deaths by forcing women to undergo dangerous back street abortions. An estimated 35,000 clandestine abortions take place in El Salvador every year. The rights group says that scores of women have been wrongly convicted of murder and imprisoned when they in fact suffered miscarriages, stillbirths or pregnancy complications. Of the 147 women prosecuted for abortion-related crimes between 2000 and 2014, 25 remain in jail, with some serving sentences as long as 40 years, the CFDA says. The legal ban particularly affects poor women, who cannot travel abroad to private clinics (4).

Resistance to changes to the ban comes not only from the Catholic church and evangelical groups, but from conservative lawmakers and the left-wing ruling FMLN party that fears alienating voters.

\section{Scenario}

A woman, from one of the barrios of the capital, San Salvador, presents at a local clinic for her first prenatal visit when she is 20 weeks pregnant. She gives a history that is consistent with an acute ZIKV infection when she was 12 weeks pregnant. The doctor tests her for ZIKV and she has antibodies consistent with a past infection. A brain scan shows evidence of early calcifications. The doctor informs the patient of her findings and the consequences of ZIKV for the foetus. The woman is devastated. She has three other children less than seven years of age and her husband is a day labourer. The patient pleads with the doctor to give her advice on what she can do to prevent the birth. The doctor, who supports a woman's right to choose and is a member of CFDA, knows that safe abortions can be performed within the city at a price that may be affordable to the woman. 
- What should the doctor recommend?

- Should the doctor give the woman a set of choices that include an illegal act, punishable under the law?

- What if the patient cannot afford an in-country abortion?

- Does the doctor have a duty to her patient that transcends the law of the land?

- Does it matter what the doctor's personal beliefs on abortion are?

- Does it matter that El Salvador is a democracy and a majority supports highly restrictive abortion laws?

- Does it matter that according to a recent Pan American Health Organization guidance document, all governments are bound by a duty to provide information, respect the right to choose, and provide access to comprehensive reproductive health care and social support to women affected by ZIKV and their children?(2)

\section{References}

1. The right(s) approach to Zika. The Lancet Glob Health. 2016 Jul;4(7):e427. doi: 10.1016/S2214-109X(16)30109-7.

2. Pan American Health Organization. Zika Ethics Consultation: Ethics guidance on key issues raised by the outbreak. Washington, DC: PAHO; 2016 Apr 6-7. Available from: http://iris.paho.org/xmlui/ handle/123456789/28425

3. Wooden C. In Zika outbreak, contraceptives may be 'lesser evil,' pope says. Catholic New Service. 2016 Feb 19 [cited 2018 Feb 19]. Available from; http://www.catholicnews.com/services/englishnews/2016/inzika-outbreak-contraceptives-may-be-lesser-evil-pope-says.cfm

4. Moloney A. Zika looms but El Salvador stands firm on abortion ban. Reuters.com. 2016 May 23 [cited 2018 Feb 19]. Available from: https:// www.reuters.com/article/us-abortion-el-salvador/zika-looms-but-elsalvador-stands-firm-on-abortion-ban-idUSKCNOYE1FD

\section{COMMENTARY}

\section{When fiduciary duty clashes with duty to the state}

\section{RAKHI GHOSHAL}

\begin{abstract}
In their case study Cash and Castro discuss a situation where a physician's duties to the laws of her land stand in conflict with her fiduciary duties to her patient. This present commentary is a response to the situation they describe, and it engages with the issue of conscientious objection in medicine, to argue that the ethical responsibility of the physician should be tilted in favour of the patient, especially when the laws of the land are regressive and harmful.
\end{abstract}

Despite the reporting of a few cases of Zika virus (ZIKV) in India (1), ZIKV did not turn into an epidemic the way it did in countries such as El Salvador. However, the questions raised by Cash and Castro in their case study in El Salvador (2) are relevant to the Indian context, particularly because the issues are embedded in a larger social structure where women's rights and voices are stifled and denied; and also because the authors urge discussion on a very critical issue in healthcare deliverythat of conscientious objection in medicine.

The authors have described a situation where a provider's duty to her government/state clashes with her fiduciary duty to her patient against a background where abortion is criminalised

\footnotetext{
Author: Rakhi Ghoshal (rakhi.ghoshal@gmail.com), Bioethics and Social Science Researcher, B3, Spandan Apts., Kalikapur, Kolkata 700078, INDIA.

To cite: Ghoshal R. When fiduciary duty clashes with duty to the state. Indian J Med Ethics. 2018 Apr-Jun;3(2) NS:164-7. DOI: 10.20529/IJME.2018.034

Manuscript Editor: Sandhya Srinivasan

(c) Indian Journal of Medical Ethics 2018
}

even when the foetus is afflicted with a severe infection such as ZIKV. Abortion laws in India are comparatively liberal' (3); the 2014 amendments to the MTP Act have added to its strengths (4). But that does not mean that the Indian state is truly sensitive to women's needs or prioritises their rights. A statewhether El Salvador or India-and the legal mechanisms it embodies are commonly patriarchal, and questions of ethics stem from the larger socio-legal framework, whether we talk of the right to abortion per se in El Salvador, or the right to abort beyond 20 weeks in India', or other laws pertaining to women's right to their own bodies, such as the right to abort without the spouse's consent, or the right to contraceptives. In this commentary, I address the questions posed by Cash and Castro and examine the larger issues that are thrown up.

\section{What should the doctor recommend?}

To recommend is to put forward a suggestion, approve of some process or action. In this case, the doctor's function would not be to recommend anything right away but primarily to ensure that the woman is able to take an informed decision. However, as evident, the extent and scope of the decision being truly informed is rather limiting under the given set of circumstances, and because of these constraints, it becomes all the more important for the provider to offer information and explanation to the woman. The woman needs to understand the implications of giving birth to the foetus, as also the consequences of opting for an abortion in the current legal regime. After thinking through her options and their respective 